\title{
Ammonia emissions in Europe, part I: Development of a dynamical ammonia emission inventory
}

\author{
Anna Backes ${ }^{\mathrm{a},{ }^{*},}$, Armin Aulinger ${ }^{\mathrm{a}}$, Johannes Bieser ${ }^{\mathrm{a}, \mathrm{b}}$, Volker Matthias ${ }^{\mathrm{a}}$, Markus Quante ${ }^{\mathrm{a}}$ \\ ${ }^{a}$ Helmholtz-Zentrum Geesthacht, Institute of Coastal Research, Max-Planck-Strasse 1, 21502 Geesthacht, Germany \\ ${ }^{\mathrm{b}}$ Deutsches Zentrum für Luft- und Raumfahrt (DLR), Institut für Physik der Atmosphäre, Oberpfaffenhofen, 82234 Weßling, Germany
}

\section{H I G H L I G H T S}

- We present an evaluated dynamical ammonia emission inventory.

- The inventory is suitable to compare and assess ammonia abatement strategies.

- CMAQ model run of temporal parameterization influences on sec. aerosol formation.

- Correlation coefficient of $\mathrm{NH}_{3}$ improved significantly for 12 out of 16 EMEP stations.

\section{A R T I C L E I N F O}

\section{Article history:}

Received 12 February 2015

Received in revised form

14 January 2016

Accepted 20 January 2016

Available online 22 January 2016

\begin{abstract}
A B S T R A C T
Nitrogen input from agricultural ammonia emissions into the environment causes numerous environmental and health problems. The purpose of this study is to present and evaluate an improved ammonia emission inventory based on a dynamical temporal parameterization suitable to compare and assess ammonia abatement strategies. The setup of the dynamical time profile (DTP) consists of individual temporal profiles for ammonia emissions, calculated for each model grid cell, depending on temperature, crop type, fertilizer and manure application, as well as on local legislation. It is based on the method of Skjøth et al., 2004 and Gyldenkærne et al., 2005. The method has been modified to cover the study area and to improve the performance of the emission model. To compare the results of the dynamical approach with the results of the static time profile (STP) the ammonia emission parameterizations have been implemented in the SMOKE for Europe emission model. Furthermore, the influence on secondary aerosol formation in the North Sea region and possible changes triggered through the use of a modified temporal distribution of ammonia emissions were analysed with the CMAQ chemistry transport model. The results were evaluated with observations of the European Monitoring and Evaluation Programme (EMEP). The correlation coefficient of $\mathrm{NH}_{3}$ improved significantly for 12 out of 16 EMEP measurement stations and an improvement in predicting the Normalized Mean Error can be seen for particulate $\mathrm{NH}_{4}^{+}$ and $\mathrm{NO}_{3}^{-}$. The prediction of the 95th percentile of the daily average concentrations has improved for $\mathrm{NH}_{3}$, $\mathrm{NH}_{4}^{+}$and $\mathrm{NO}_{3}^{-}$. The $\mathrm{NH}_{3}$ concentration modelled with the STP is $157 \%$ higher in winter, and about $22 \%$ lower in early summer than the one modelled with the new DTP. Consequently, the influence of the DTP on the formation of secondary aerosols is particularly noticeable in winter, when the $\mathrm{PM}_{2.5}$ concentration is $25 \%$ lower in comparison to the use of STP for temporal disaggregation. Besides, the formation of particulate $\mathrm{SO}_{4}^{2-}$ is not influenced by the use of the DTP.
\end{abstract}

(c) 2016 Elsevier Ltd. All rights reserved.

\section{Introduction}

Emissions of reactive nitrogen into the atmosphere cause numerous problems of global significance, such as air pollution,

\footnotetext{
* Corresponding author.

E-mail address: anna.backes@hzg.de (A. Backes).
}

eutrophication and soil acidification (Erisman et al., 2008; van Grinsven et al., 2013). The main components of reactive nitrogen are $\mathrm{NO}_{\mathrm{x}}$ arising from transport or power generation and agricultural ammonia $\left(\mathrm{NH}_{3}\right.$ ) (Fowler et al., 2013). As there has been little progress in controlling agricultural ammonia emissions, their share in European air pollution is constantly increasing (Velthof et al., 2014; Sutton et al., 2011). The share of agriculture related $\mathrm{NH}_{3}$ 
emissions ranges between 85 and 99\% in countries with high agricultural activity, such as e.g. Denmark (FAOSTAT, 2014; Schulze et al., 2010). Political restrictions as the National Emission Ceilings Directive (NECD) are often based on reported annual emissions of the member states, which make the future use of more accurate emission inventories, including agricultural procedures, likely (Hutchings et al., 2001).

"This is likely to mean emission inventories become more complex in the future. We believe this extra complexity may be justified, particularly for countries with the highest animal densities" (Hutchings et al., 2001)

Ammonium sulphate $\left(\left(\mathrm{NH}_{4}\right)_{2} \mathrm{SO}_{4}\right)$ and ammonium nitrate $\left(\mathrm{NH}_{4} \mathrm{NO}_{3}\right)$ make up a large fraction of fine particles (Anderson et al., 2003; Hristov, 2011; Werner et al., 2014), which pose a threat to human health (Aneja et al., 2009). As pointed out by Dentener et al. (2006) most model studies focus on the influence of emission reductions of sulphur- and nitrogen oxides on aerosol concentration. This study, however, has the aim of generating a better understanding of the ammonia emission distribution with regard to the geographical-, as well as the temporal aspect. The detailed, evaluated and applicable model was particularly designed to fit the needs of scenario studies (Backes et al., 2015) for investigating the influence of different ammonia abatement strategies on the formation of particles. Diverse studies suggested that a temporal component based on meteorological variables should be considered when applying ammonia emissions in a chemistry transport model (CTM) due to their high temporal variability (Hutchings et al., 2001; Skjøth et al., 2004; Gyldenkærne et al., 2005; Huang et al., 2012; Sutton et al., 2012; Reis et al., 2011). In this study, a parameterization was developed based on the dynamical ammonia emission parameterization by Skjøth et al., 2004 and presented in detail by Gyldenkærne et al., 2005. A profile named STP represents the time profile used to disaggregate ammonia emissions as presented in Schaap et al., 2005. The DTP was developed and applied to ammonia emissions in the here presented study. Recent studies (Skjøth et al., 2011; Megaritis et al., 2013) recommended the further analysis of the dynamical parameterization of ammonia on its transformation products with CTMs, even though this makes it more difficult to trace errors back to the time profile (Pinder et al., 2006). Therefore in this study the distribution of ammonia in the atmosphere and the contribution to the formation of secondary aerosols were modelled with the Community Multiscale Air Quality model (CMAQ). SMOKE for Europe (Bieser et al., 2011) served to prepare a model ready emission inventory for this CTM and EMEP observations were used to evaluate the results.

\section{Methods and model description}

The method and model description section includes a brief introduction to the emission model SMOKE for Europe, the applied time profiles and the emission inventories that have been used. Additionally the CTM CMAQ is described here with special focus on the implementation of the atmospheric transformation processes of gaseous $\mathrm{NH}_{3}$ into particulate $\mathrm{NH}_{4}^{+}, \mathrm{SO}_{4}^{2-}$ and $\mathrm{NO}_{3}^{-}$.

\subsection{Emission model SMOKE for Europe and the used emission inventories}

The anthropogenic and biogenic emissions were processed by the emission model SMOKE for Europe (Bieser et al., 2011). SMOKE for Europe is the official emission model of the Community Modelling and Analysis System (CMAS) (Byun and Ching, 1999; Byun and Schere, 2006). Setting up and evaluating different ammonia emission scenarios, like done in a follow-up study (Backes et al., 2015), requires a sectorized emission inventory to ensure that different $\mathrm{NH}_{3}$ emission sectors can be analysed separately. The Emissions Database for Global Atmospheric Research (EDGAR) consists of eleven emission sectors two of which are related to agriculture: Emissions from Agricultural Soils and Manure Management (EDGAR, 2009). This distinction of the inventory allows differentiated research on the influences of animal farming and crop farming, necessary for abatement strategy assessments. Furthermore, in contrast to the officially reported national emissions from EMEP, the EDGAR data set represents a bottom-up inventory based on expert estimates, activity data and emission factors (Hertel et al., 2011). The temporal profiles described in the next section have been applied to the sectors Emissions from Agricultural Soils and Manure Management based on the data analysis which revealed that $96 \%$ of the total European ammonia emission is caused by subsectors grouped in these two emission sectors. Within the study area the share of Manure Management accounts for 53\% and the share of Emissions from Agricultural Soils for $43 \%$ of the ammonia emissions (see appendix table A3). Ammonia emissions from the sectors industry and transport, which made up 4\% of the ammonia emissions used in this study, were taken from the according EMEP SNAP (Selected Nomenclature for sources of Air Pollution) sectors (European Environmental Agency, 2007). Due to their small share in total European emissions they were not replaced by the remaining nine EDGAR non-agricultural sectors.

It has been concluded in previous studies that atmospheric concentrations of $\mathrm{NH}_{3}$ highly depend on the emission time profile and that therefore, the temporal component should be considered when implementing ammonia emissions for CTM modelling, preferably through meteorological variables (Denier van der Gon et al., 2011; Hutchings et al., 2001).

\subsubsection{Static time profile (STP)}

The STP is the commonly used temporal disaggregation scheme for ammonia emissions in current CTMs for Europe (compare AQMEII (Pouliot et al., 2012), Eurodelta III (EMEP, 2014) and COST 728 (World Meteorological Organization, 2008). The STP (Fig. 2) was adopted from the LOTOS-EUROS documentation (Schaap et al., 2005). It represents the SNAP sector level 1, category 10 (agriculture). A daily or weekly factor was not defined (Schaap et al., 2005); while a static hourly profile is included. The profile is static in the sense that the same profile was applied to every grid cell in the model domain. It lacks a dynamic, meteorology dependent component or the consideration of country specific differences in policies or intensity of animal husbandry. As the emission of ammonia is highly dependent on temperature, the missing variability is expected to be a considerable limitation. Denier van der Gon et al. (2011) tested the sensitivity of air quality models to temporal distribution of emissions and recommends an implementation of meteorology dependent functions.

\subsubsection{Dynamical time profile (DTP)}

Like the STP, the DTP was applied to the geographically distributed annual bulk emissions of the gridded EDGAR emission sectors Emissions from Agricultural Soils and Manure Management. In this approach, the annual emissions of the inventory have been temporally distributed across the year on the basis of the meteorological variables wind speed and surface temperature, resulting in individual ammonia emission data for every grid cell and every hour. Parts of the newly developed parameterization are a modified version of the dynamical ammonia emission parameterization by Skjøth et al. (2004) and Gyldenkærne et al. (2005), which is currently considered as a substantial improvement of the available ammonia emission estimates (Pinder et al., 2007). To improve the 


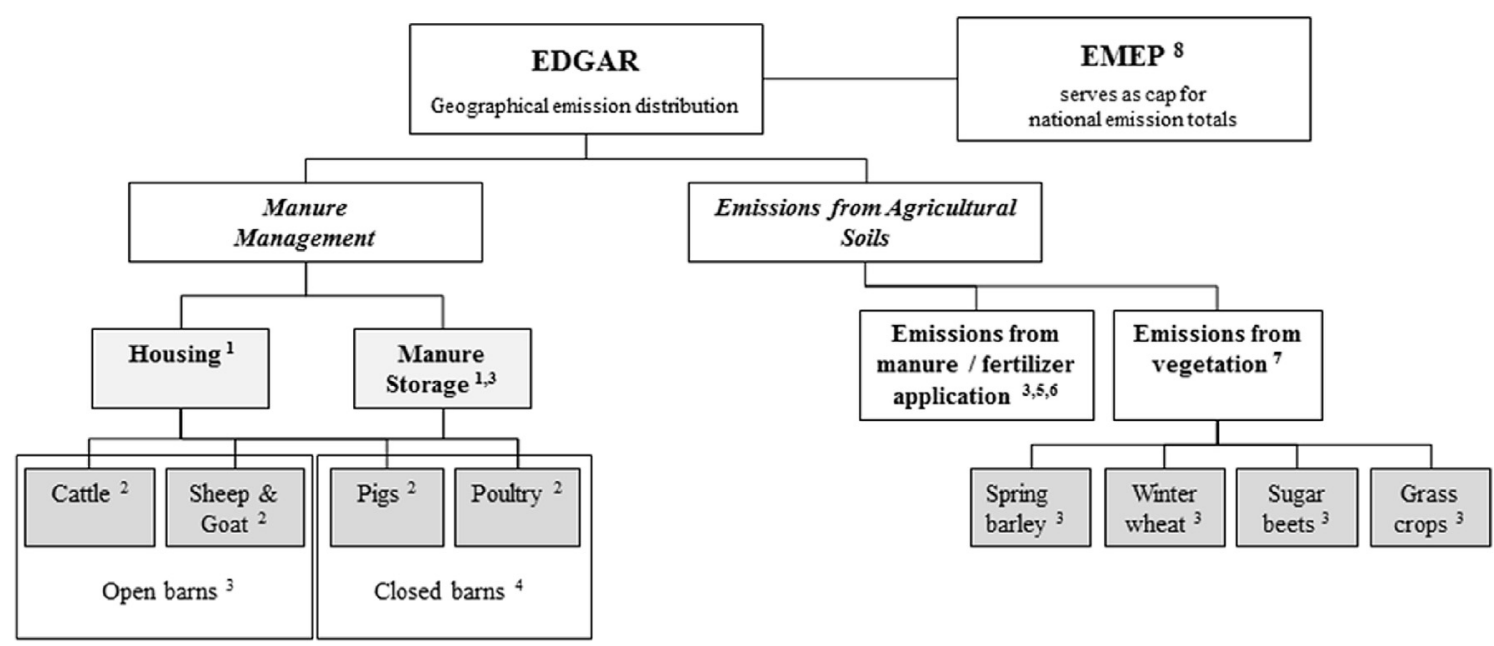

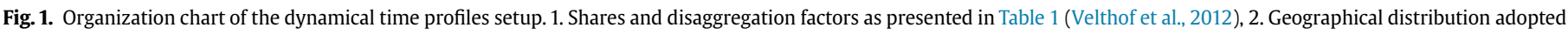

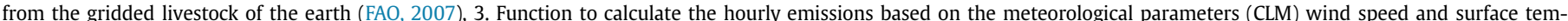

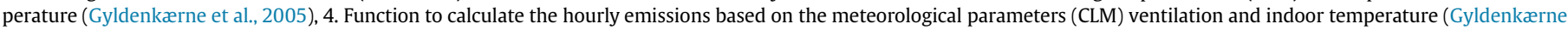

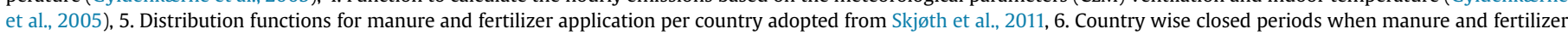

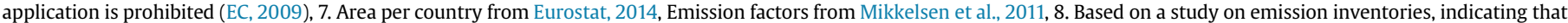
EDGAR delivers overestimated emission values (De Vries et al., 2011).

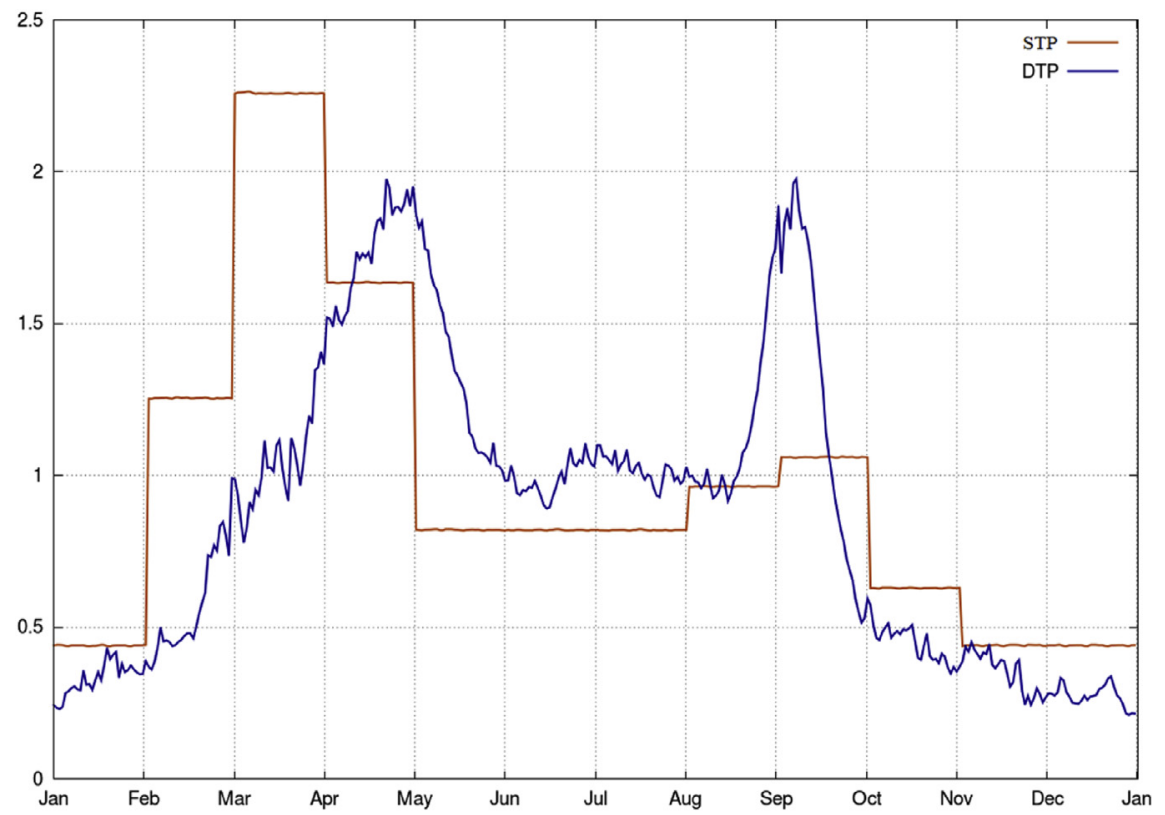

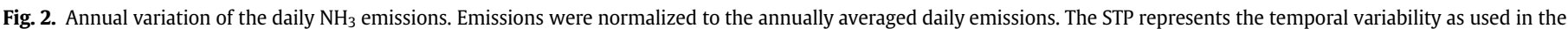

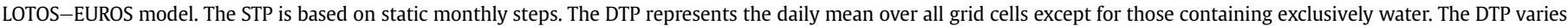
from grid cell to grid cell depending on meteorology and other features such as e.g. the amount of animals.

reliability of the approach, modifications were applied especially in the animal husbandry related Manure Management Sector by creating a more detailed set of subsectors. Other additions to the method have been made with the subsector emissions from vegetation or through applying country-wise political restrictions.

To calculate the temporal emission profile using wind speed and surface temperature has been found to be a feasible approach for usage in large scale CTMs (Hertel et al., 2011). Model wind speed is at $10 \mathrm{~m}$ and temperature at $2 \mathrm{~m}$, as it is standard in meteorological observations. Both were taken from the mesoscale meteorology model COSMO-CLM (Doms and Schättler, 2002), that delivers the meteorological input data for CMAQ.
Reinforced by recent studies (Dentener et al., 2006; Anderson et al., 2003) the emissions of the livestock related sector Manure Management were split into four layers based on the Food and Agriculture Organizations (FAO) gridded livestock of the world (FAO, 2007) and differ therefore from the approach by Gyldenkærne et al. (2005). The Manure Management sector consists of the subsectors Houses with forced Ventilation, Open Barns and Manure Storage (Gyldenkærne et al., 2005). Each of the subsectors' temporal emission distribution is calculated with an individual formula including indoor-, outdoor- and surface temperature as well as wind speed or ventilation variables. The shares of the emission subsectors Housing and Manure storage were calculated 
based on the study by Velthof et al. (2012), as presented in Table 1 on the basis of the 4 different animal species layers of FAO. Within the housing subsector, ruminants are grouped in open barns, pigs and poultry in closed barns. The emission per species and subsector has been distributed on the basis of the disaggregation factors. In the approach of Skjøth et al. (2011) the emissions related to animal husbandry have country-wise factors, neither specifically differentiated according to animal species further than closed barns (pigs and poultry) and open barns (cattle), nor respecting a regional distribution below country level. The modified approach using the FAO gridded livestock of the earth is expected to give a more detailed and accurate picture of the emissions related to animal husbandry.

As presented in the organization chart Fig. 1, the Emissions from Agricultural Soils sector consist of two subsectors: Emissions from manure/fertilizer application and Emissions from vegetation. The distribution factors of emissions from manure- /fertilizer application individual for most European countries were adopted from Skjøth et al., 2011. For European countries not mentioned in this study the average value of the factor was used.

In contrast to other approaches, different policy restrictions concerning closed periods were included (European Nitrates Directive EC, 1991). During closed periods, which are different for every member state (Webb et al., 2010), the application of manure and/or fertilizer is prohibited. In countries with a federal system the closed periods differ from region to region (EC, 2009). The closed periods used in this study represent therefore a simplified version of reality as they don't differentiate between regional legislations. Table A2 (appendix) gives an overview on the closed periods applied.

Skjøth et al. (2011) disregarded the contribution of crops to ammonia emissions, due to the lack of data. However this was identified as an evident weakness in the inventory by the authors of the study themselves. Here, the parameterization for modifying the subsector Emissions from vegetation was extended by four categories related to the direct emissions from crops. The crop growth parameters used in the original parameterization, defining the temporal distribution, are based on the four crop types spring barley, winter wheat, sugar beets and grass crops (Gyldenkærne et al., 2005). The share of each vegetation's emission per country was calculated with reference to the emission factors provided by the Danish emission inventory (Mikkelsen et al., 2011), where $0.5 \mathrm{~kg} \mathrm{~N} /$ ha per year is emitted from grassland and $2 \mathrm{~kg} \mathrm{~N} /$ ha per year from all other crops. Then the shares of these crops in the total utilized agricultural area (UAA) of the individual countries were used to apportion the emissions (Eurostat, 2014) in relation to the total annual emission of the country in question.

The comparison of emission models by De Vries et al., 2011, where the uncertainties in $\mathrm{NH}_{3}-\mathrm{N}$ modelling are described, revealed that the EDGAR emission inventory has much higher values than other inventories and seems to overestimate the $\mathrm{NH}_{3}$ emissions. To avoid overestimated emission values a cap which limits the country totals to the EMEP country totals has been implemented. Nevertheless, the usage of the EDGAR emission inventory was preferred due to the separation of the emissions in the

Table 1

The share of the species that they hold in the different subsectors and the disaggregation factors calculated on the basis of Velthof et al. (2012).

\begin{tabular}{llll}
\hline & Housing & Manure storage & Disaggregation factors \\
\hline Cattle & $96.13 \%$ & $3.87 \%$ & 0.7 \\
Pigs & $98.10 \%$ & $1.9 \%$ & 0.19 \\
Poultry & $89.47 \%$ & $10.53 \%$ & 0.01 \\
Sheep \& Goat & $80 \%$ & $20 \%$ & 0.1 \\
\hline
\end{tabular}

two sectors Manure Management and Emissions from Agricultural Soils.

\subsection{Chemistry transport model CMAQ}

CMAQ was used to investigate the influence of the temporal distribution of $\mathrm{NH}_{3}$ emissions on secondary aerosol formation and atmospheric $\mathrm{NH}_{3}$ concentrations. The CMAQ 4.7.1 modelling system was set up with the SMOKE for Europe emission model and COSMO-CLM 4.8 meteorological fields (Consortium for Small-scale Modelling - Climate Limited-area Model). The model simulates chemical transport, transformation and deposition of air pollutants (Byun and Ching, 1999). Gas phase, aerosol and aquatic chemistry are included, as well as primary and secondary particles. The modelling domain was set up over north-west Europe with a grid cell size of $24 \times 24 \mathrm{~km}^{2}$ and 30 vertical layers (Fig. 3). This domain was chosen due to the enclosed European ammonia hotspots. The Carbon Bond 5 (CB 05) photochemical mechanism was used in this model and the monthly average boundary conditions were derived from monthly means of the TM5 global chemistry transport model system (Huijnen et al., 2010), provided by the Dutch Royal Meteorological Institute (KNMI). The meteorological fields were derived from the regional, non-hydrostatic atmospheric circulation model COSMO-CLM 4.8 (Rockel and Geyer, 2008; Rockel et al., 2008). Meteorological data for the year 2008 was taken, as this year has not shown unusual meteorological events. PM represents the sum of all particles listed: $\mathrm{SO}_{4}, \mathrm{NO}_{3}, \mathrm{NH}_{4}, \mathrm{Cl}$, black carbon, mineral dust, sea salt and organic aerosols. With this setup, two CMAQ runs using the different temporal emission distributions STP and DTP (sections 2.1.1 and 2.1.2) were performed.

\subsubsection{Atmospheric transformation of ammonia as implemented in CMAQ}

The atmospheric transformation of ammonia is implemented in CMAQ as a condensation process onto existing aerosols or, respectively, as a reaction with gas phase acids forming secondary aerosols. The state of the art ISORROPIA module version 1.7 has been used (Nenes et al., 1998). If present, gaseous $\mathrm{NH}_{3}$ preferentially reacts with sulphuric acid $\left(\mathrm{H}_{2} \mathrm{SO}_{4}\right)$ (F.1 and F.2), formed by the oxidation of $\mathrm{SO}_{2}$ (Seinfeld and Pandis, 1998).

$\mathrm{NH}_{3}+\mathrm{H}_{2} \mathrm{SO}_{4} \rightarrow \mathrm{NH}_{4} \cdot \mathrm{HSO}_{4}$

$\mathrm{NH}_{3}+\mathrm{NH}_{4} \cdot \mathrm{HSO}_{4} \rightarrow\left(\mathrm{NH}_{4}\right)_{2} \cdot \mathrm{SO}_{4}$

Only if the availability of sulphuric acid is limited, $\mathrm{NH}_{3}$ reacts with other acid gaseous compounds like nitric acid $\left(\mathrm{HNO}_{3}\right)$ (F.3) or hydrochloric acid ( $\mathrm{HCl}$ ) (F.4). The equilibrium in reaction $\mathrm{F} .3$ is temperature sensitive and will be on the right side in winter and on the left side in summer. In case of excess of sulphuric acid, the sulphate ion will replace the chloride or nitrate ion which will evaporate into the gas phase as $\mathrm{HCl}$ and $\mathrm{HNO}_{3}$, respectively.

$\mathrm{NH}_{3}+\mathrm{HNO}_{3} \leftrightarrow \mathrm{NH}_{4} \mathrm{NO}_{3}$

$\mathrm{NH}_{3}+\mathrm{HCl} \leftrightarrow \mathrm{NH}_{4} \mathrm{Cl}$

Dry and wet depositions are considered as follows. Particles undergo dry deposition depending on their actual size and wet deposition by incorporation into cloud droplets and subsequent precipitation (Binkowski and Roselle, 2003). Dry deposition of all gaseous compounds is parameterized by calculating the deposition velocities in a resistance approach that considers aerodynamic and stomatal resistance. Wet deposition depends on the solubility of gases in cloud droplets which is described by Henry's law. 


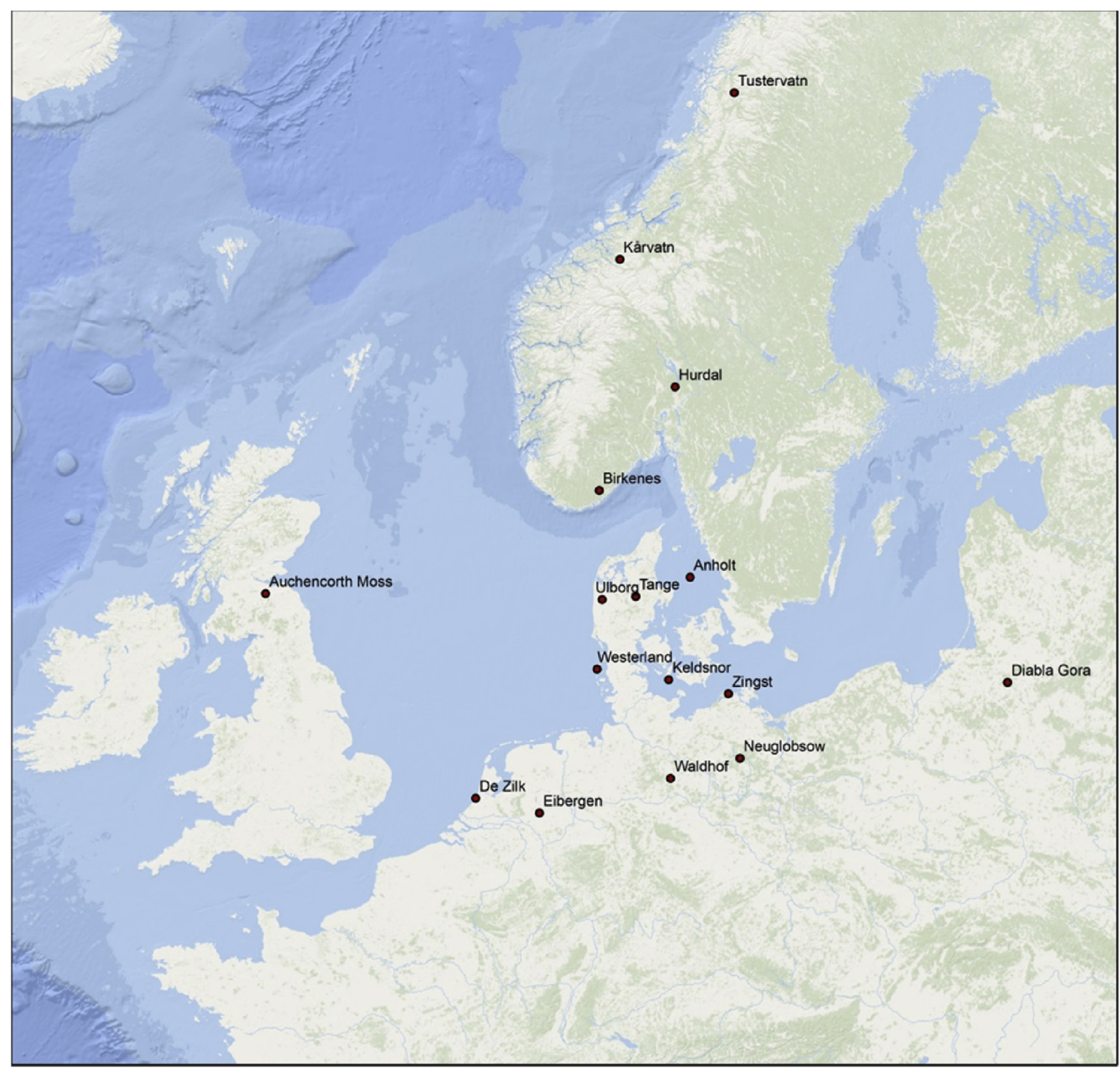

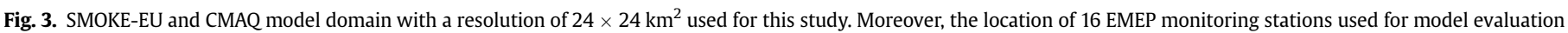
are given. The station ID and the species measured can be consulted in Table A1. The shown area is the CMAQ model domain used for this study.

\subsubsection{Measurement data to evaluate CMAQ results}

To evaluate the results, measurement data from EMEP monitoring stations was used. The focus was laid on the comparison of modelled and measured $\mathrm{NH}_{3}$ concentration as well as on its products and reaction partners $\mathrm{NH}_{4}^{+}, \mathrm{NO}_{3}^{-}, \mathrm{SO}_{4}^{2-}$ and $\mathrm{PM}_{2.5}$. Daily mean concentrations of $\mathrm{NH}_{3}$ and $\mathrm{NO}_{3}^{-}$were obtained from 16 different monitoring stations for the year 2008. 22 stations measured $\mathrm{NH}_{4}^{+}, 32$ stations measured $\mathrm{SO}_{4}^{2-}$, and 22 measured $\mathrm{PM}_{2.5}$. In order to get a statistically sound comparison, only stations with more than 100 measurements per year were considered. Fig. 3 shows the location of the stations on a map. In Table A2 (see appendix), the station names, station ID and the species measured are given.

\section{Results}

In this section the emission and concentration time series will be presented. The influence of the different time profiles on emission patterns, but also on the total amount and distribution of the concentrations will be analysed. Besides this, the evaluation of the results with the measured values of the EMEP measurement stations in Europe is part of this section. All results for atmospheric concentrations refer to the lowest model layer with an approximate vertical extent of $40 \mathrm{~m}$.

\subsection{Emissions}

The biggest difference between the temporal emission profiles can be seen in summer (June, July, August) and winter (December, January, February). The DTP shows larger emissions in summer and lower emissions in winter, while the STP emissions for summer, autumn and winter are nearly the same. Compared to the STP, in the DTP a shift from winter $\mathrm{NH}_{3}$ emissions to summer $\mathrm{NH}_{3}$ emissions has taken place. Fig. 4 indicates that the DTP emissions decrease more steadily from spring to winter than the STP emissions. The sum of $\mathrm{NH}_{3}$ emissions over all grid cells is given in Table 2.

\subsection{Concentrations}

The gases $\left(\mathrm{NH}_{3}, \mathrm{HNO}_{3}\right.$ and $\left.\mathrm{H}_{2} \mathrm{SO}_{4}\right)$ and aerosols $\left(\mathrm{NH}_{4}^{+}, \mathrm{NO}_{3}^{-}\right.$, $\mathrm{SO}_{4}^{2-}$ ) presented are observably affected by a seasonal shift in $\mathrm{NH}_{3}$ 

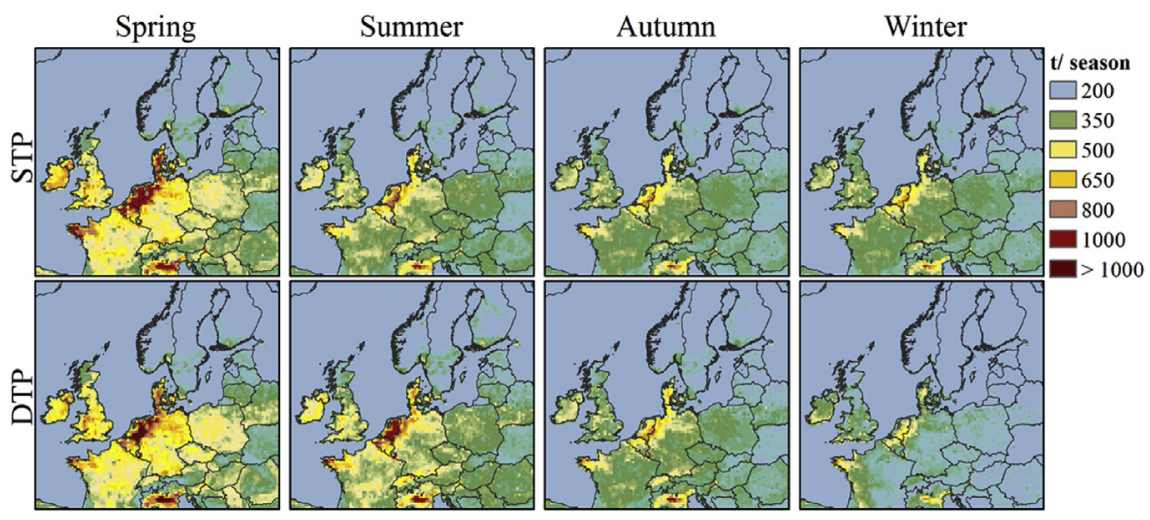

Fig. 4. Seasonal $\mathrm{NH}_{3}$ emissions in tons per season modelled with the STP and the DTP.

Table 2

Sum of $\mathrm{NH}_{3}$ emissions over all land grid cells for the STP and the DTP per season in Gg.

\begin{tabular}{lllll}
\hline & Spring & Summer & Autumn & Winter \\
\hline STP & $1705 \mathrm{Gg}$ & $965 \mathrm{Gg}$ & $794 \mathrm{Gg}$ & $771 \mathrm{Gg}$ \\
DTP & $1625 \mathrm{Gg}$ & $1279 \mathrm{Gg}$ & $811 \mathrm{Gg}$ & $466 \mathrm{Gg}$ \\
\hline
\end{tabular}

emissions. The seasonal differences of the relevant substances between the CMAQ runs with DTP and STP ammonia emissions are summarized in Table 3.

\subsubsection{Ammonia}

The analysis of the geographical pattern indicates that high $\mathrm{NH}_{3}$ concentrations appear in proximity to emission sources, due to the low atmospheric lifetime of ammonia. This results in $\mathrm{NH}_{3}$ concentration levels in the atmosphere which closely follow the seasonal emission trend. Like the emission patterns, the concentrations based on STP show one annual peak in spring. The DTP concentrations show two annual peaks (see Fig. 5), one in spring and one in autumn. It can be seen in Table 3 that the mean difference of the $\mathrm{NH}_{3}$ concentration is highest in winter $\left(0.5 \mu \mathrm{g} / \mathrm{m}^{3}\right)$ and lowest in autumn (no change). Due to the alikeness to Fig. 4, the concentration patterns are not presented as maps.

\subsubsection{Ammonium}

In contrast to $\mathrm{NH}_{3}$ the more persistent $\mathrm{NH}_{4}^{+}$aerosols are transported over greater distances. This leads to concentration patterns which cover larger areas and do not resemble the emission maps. Table 3 presents a considerable difference in the total annual concentration resulting from the time profiles DTP and STP. Again, the difference is particularly visible in the winter months (Fig. 6). The low $\mathrm{NH}_{4}^{+}$winter concentration $\left(1.36 \mu \mathrm{g} / \mathrm{m}^{3}\right)$ for the DTP run results from the shift of winter $\mathrm{NH}_{3}$ emissions to spring and summer (Table 3). The STP emissions are high in winter, which explains their higher $\mathrm{NH}_{4}^{+}$concentration $\left(1.85 \mu \mathrm{g} / \mathrm{m}^{3}\right)$. The overall high concentration levels in winter in both time profiles compared to the summer season are caused by meteorological effects (colder temperatures and therefore more ammonium nitrate in the particle phase and lower planetary boundary layer heights) and the presence of other combustion sources in this season and will be discussed in section 4.

\subsubsection{Sulphate}

The $\mathrm{SO}_{4}^{2-}$ concentrations in the DTP run change slightly in comparison to the STP run (decrease in winter by $0.11 \mu \mathrm{g} / \mathrm{m}^{3}$ ). The results presented in Table 3 indicate that the formation of $\mathrm{SO}_{4}^{2-}$ particles is not limited by $\mathrm{NH}_{3}$ in any season.

\subsubsection{Nitrate}

The seasonal $\mathrm{NO}_{3}^{-}$concentration varies, like the concentrations of $\mathrm{NH}_{4}^{+}$, considerably between the two time profiles. The decrease of $\mathrm{NH}_{3}$ emissions in winter for the DTP results in a strong decrease of particulate $\mathrm{NO}_{3}^{-}$concentrations modelled with this time profile. Higher $\mathrm{NH}_{3}$ concentrations in summer result in a slight increase in particulate $\mathrm{NO}_{3}^{-}$concentration for the DTP (see Table 3). Fig. 7 shows lower autumn concentration of particulate $\mathrm{NO}_{3}^{-}$for the DTP.

\subsubsection{Nitric acid $\left(\mathrm{HNO}_{3}\right)$}

The implementation of the DTP resulted in a strong decline of

Table 3

Mean concentrations for both static and dynamical time profile (STP and DTP). The value is given in $\mu \mathrm{g} / \mathrm{m}^{3}$ and represents the mean value over all land cells.

\begin{tabular}{|c|c|c|c|c|c|c|}
\hline Species & Time profile & Spring $\mu \mathrm{g} / \mathrm{m}^{3}$ & Summer $\mu \mathrm{g} / \mathrm{m}^{3}$ & Autumn $\mu \mathrm{g} / \mathrm{m}^{3}$ & Winter $\mu \mathrm{g} / \mathrm{m}^{3}$ & Annual mean \\
\hline \multirow[t]{2}{*}{$\mathrm{NH}_{3}$} & DTP & 1.54 & 1.34 & 0.84 & 0.31 & 1.01 \\
\hline & STP & 1.62 & 1.04 & 0.84 & 0.81 & 1.08 \\
\hline \multirow[t]{2}{*}{$\mathrm{NH}_{4}^{+}$} & DTP & 1.15 & 0.66 & 1.10 & 1.36 & 1.06 \\
\hline & STP & 1.29 & 0.63 & 1.22 & 1.85 & 1.25 \\
\hline \multirow[t]{2}{*}{$\mathrm{SO}_{4}^{2-}$} & DTP & 1.92 & 1.63 & 1.87 & 2.10 & 1.88 \\
\hline & STP & 1.99 & 1.63 & 1.88 & 2.21 & 1.93 \\
\hline \multirow[t]{2}{*}{$\mathrm{NO}_{3}^{-}$} & DTP & 1.83 & 0.48 & 1.84 & 2.67 & 1.71 \\
\hline & STP & 2.15 & 0.41 & 2.19 & 3.95 & 2.18 \\
\hline \multirow[t]{2}{*}{$\mathrm{HNO}_{3}$} & DTP & 0.36 & 0.48 & 0.66 & 0.85 & 0.58 \\
\hline & STP & 0.26 & 0.51 & 0.54 & 0.49 & 0.45 \\
\hline \multirow[t]{2}{*}{$\mathrm{N}$} & DTP & 3.60 & 2.53 & 3.28 & 4.01 & 3.36 \\
\hline & STP & 3.82 & 2.26 & 3.43 & 5.00 & 3.63 \\
\hline \multirow[t]{2}{*}{$\mathrm{PM}_{2.5}$} & DTP & 5.85 & 3.43 & 5.97 & 7.84 & 5.77 \\
\hline & STP & 6.40 & 3.33 & 6.47 & 9.80 & 6.5 \\
\hline
\end{tabular}




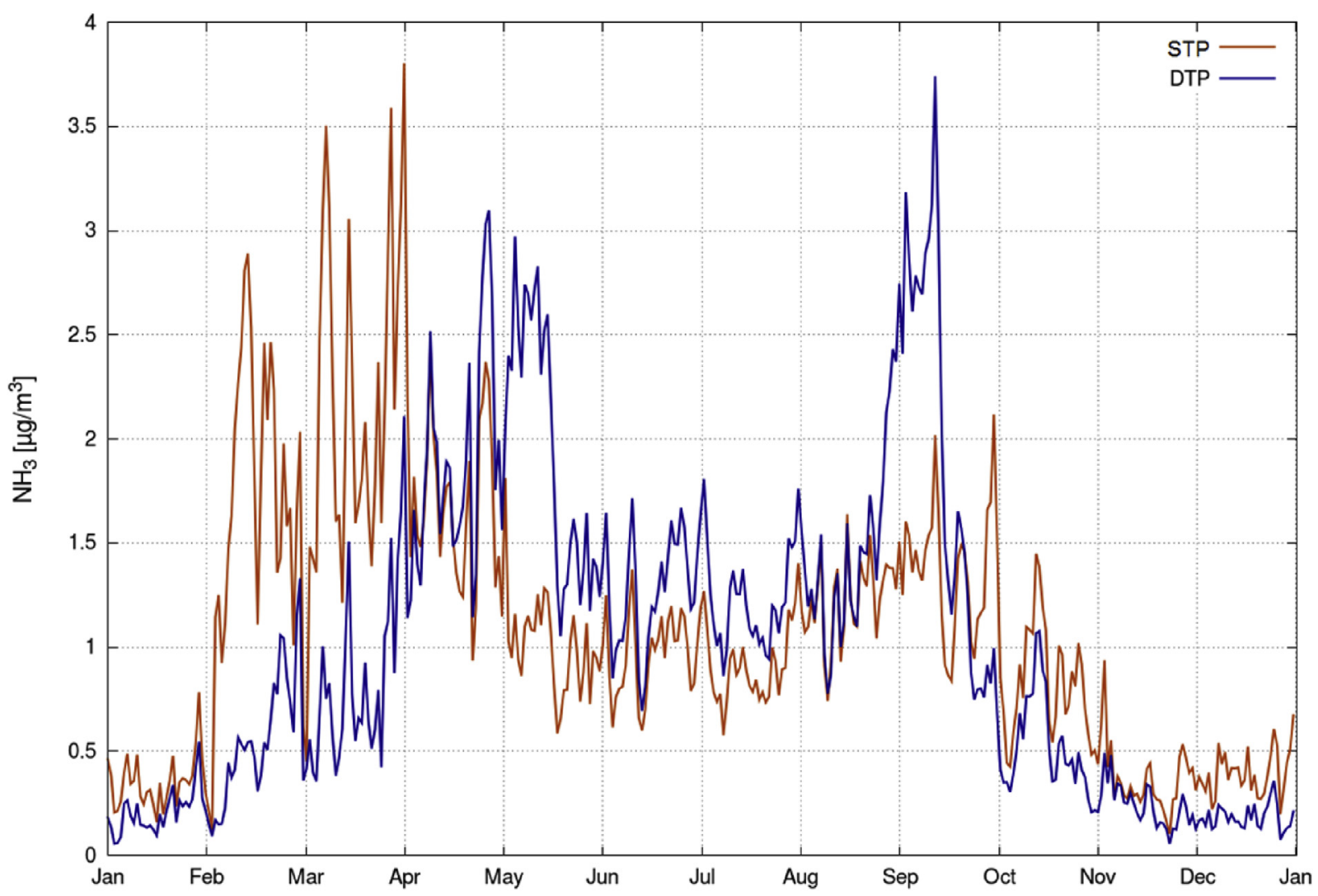

Fig. 5. Annual time series of $\mathrm{NH}_{3}$ concentrations modelled with the STP and the DTP. Daily mean values have been calculated as mean over all land cells.

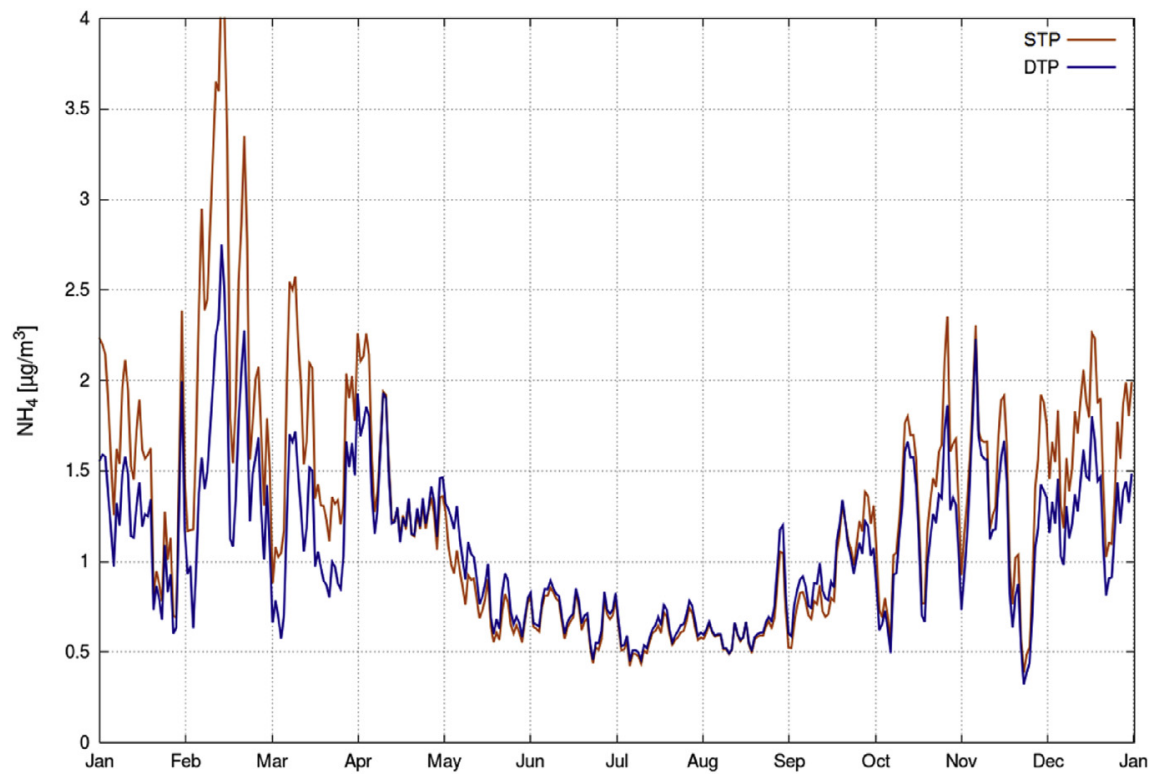

Fig. 6. Time series of particulate $\mathrm{NH}_{4}^{+}$concentrations modelled with the STP and the DTP. The daily mean values have been calculated over all land cells

particulate concentrations in the cold seasons, see Figs. 6 and 7. Fig. 8 depicts that due to the limitation of the $\mathrm{NO}_{3}^{-}$formation process through $\mathrm{NH}_{3}$ a shift towards higher gas phase $\mathrm{HNO}_{3}$ concentration takes place. The concentration of gaseous $\mathrm{HNO}_{3}$ modelled with the STP is about $43 \%$ lower compared to the DTP during winter. A possible overestimation of $\mathrm{HNO}_{3}$ is discussed in chapter 4 .
3.2.6. $P M_{2.5}$

The modelled change in $\mathrm{PM}_{2.5}$ concentration between the two scenarios is driven by the reduction of ammonium nitrate formation. Thus, the results are in line with the findings discussed in Sections 3.2.2 and 3.2.4. On annual average the $\mathrm{PM}_{2.5}$ concentration is reduced by $12 \%$ ( $-17 \%$ spring, $+3 \%$ summer, $-8 \%$ autumn, $-20 \%$ winter) in the DTP run. 


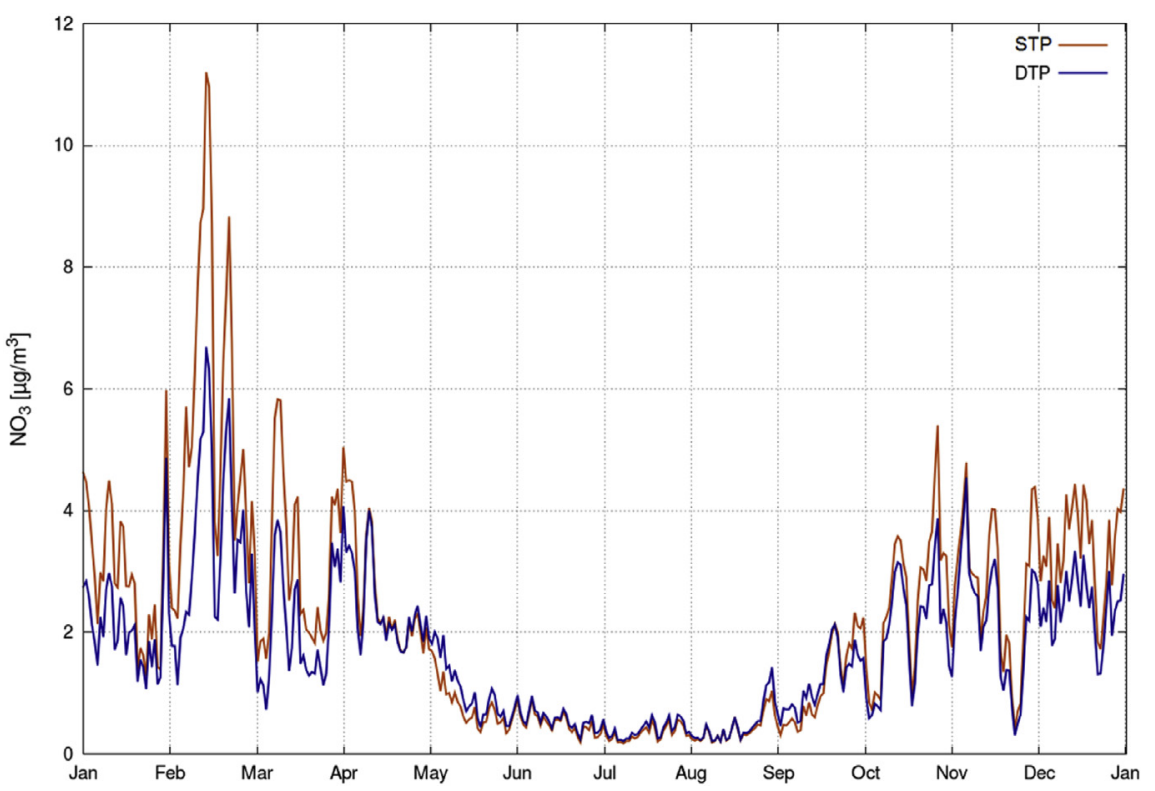

Fig. 7. Time series of particulate $\mathrm{NO}_{3}^{-}$concentrations modelled with the STP and the DTP. The daily mean values have been calculated over all land cells.

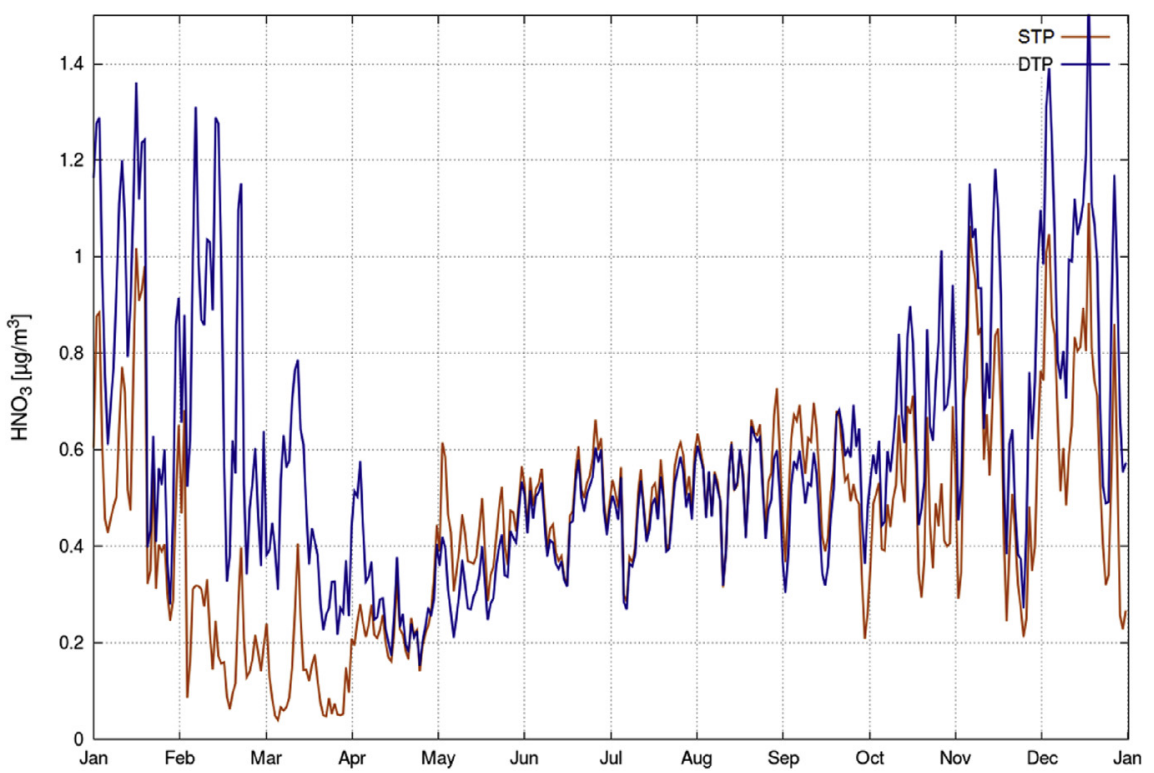

Fig. 8. Time series of $\mathrm{HNO}_{3}$ concentrations modelled with the STP and the DTP. The daily mean values have been calculated over all land cells.

\subsection{Evaluation with EMEP data}

To compare the two modelling approaches STP and DTP the predicted concentration values for the species $\mathrm{NH}_{3}, \mathrm{NH}_{4}^{+}, \mathrm{NO}_{3}^{-}$, $\mathrm{HNO}_{3}$ and $\mathrm{SO}_{4}^{2-}$ were compared with EMEP observations. Assessing an emission parameterization through a comparison of atmospheric concentration values means an evaluation of the whole modelling chain. Although to distinct between the error derived by the emission model, the meteorological model, the CTM, the measuring errors and the errors of the temporal parameterization of the emissions requires a targeted interpretation (Pinder et al., 2006), this has been found to be an adequate method. Only stations that provided more than 100 daily average values per year were included in the comparison. The stations used to evaluate the results are presented in Fig. 3. For a detailed description see
Table A1 in the supplementary material.

The results in Table 4 show that the spearman correlation of measured and modelled $\mathrm{NH}_{3}$ concentration has improved significantly for 12 out of 16 European EMEP measurement stations. The improvement is particularly visible for the German and Danish stations where it has been as high as from 0.03 to 0.41 for Neuglobsow. The statistical significance of the correlation improvement was assessed by applying the Fisher z-transformation to the correlation coefficients and testing the alternative hypothesis "greater than" at a level of significance of 95\%. Time series for selected stations are given in Fig. 9.

Table 5 presents the normalized mean error (NME), the normalized mean bias (NMB), the median, the 95th percentile for observation and prediction, and the sample size N. All values measured at the EMEP stations listed in appendix A1 have been 
Table 4

Spearman correlation between measured and modelled $\mathrm{NH}_{3}$ concentrations achieved with DTP and STP and the results of the significance test.

\begin{tabular}{|c|c|c|c|c|}
\hline \multirow[t]{2}{*}{ Station } & \multirow{2}{*}{$\frac{\text { DTP } \mathrm{NH}_{3}}{\text { Correlation }}$} & \multirow{2}{*}{$\frac{\mathrm{STP} \mathrm{NH}_{3}}{\text { Correlation }}$} & \multirow{2}{*}{$\begin{array}{l}\text { Significant } \\
\text { improvement }\end{array}$} & \multirow{2}{*}{$\begin{array}{l}\text { Significance } \\
\text { level } \\
\text { of the } \\
\text { improvement }\end{array}$} \\
\hline & & & & \\
\hline Westerland & 0.57 & 0.42 & $\mathbf{x}$ & 0.99 \\
\hline Waldhof & 0.38 & 0.19 & $\mathbf{x}$ & 0.99 \\
\hline Neuglobsow & 0.41 & 0.03 & $\mathbf{x}$ & 1 \\
\hline Zingst & 0.45 & 0.28 & $\mathbf{x}$ & 0.98 \\
\hline Tange & 0.45 & 0.3 & $\mathbf{x}$ & 0.99 \\
\hline Keldsnor & 0.47 & 0.37 & & 0.93 \\
\hline Anholt & 0.55 & 0.4 & $\mathbf{x}$ & 0.98 \\
\hline Ulborg & 0.7 & 0.6 & $\mathbf{x}$ & 0.98 \\
\hline $\begin{array}{l}\text { Auchencorth } \\
\text { Moss }\end{array}$ & 0.4 & 0.3 & & 0.86 \\
\hline Eibergen & 0.61 & 0.49 & $\mathbf{x}$ & 0.99 \\
\hline De Zilk & 0.6 & 0.53 & & 0.9 \\
\hline Birkenes & 0.5 & 0.2 & $\mathbf{x}$ & 1 \\
\hline Tustervatn & 0.3 & 0.03 & $\mathbf{x}$ & 1 \\
\hline Kårvatn & 0.43 & 0.19 & $\mathbf{x}$ & 1 \\
\hline Hurdal & 0.25 & 0.16 & & 0.88 \\
\hline Diabla Gora & 0.04 & -0.14 & $\mathbf{x}$ & 0.99 \\
\hline
\end{tabular}

included for the evaluation. The correlation is not given in Table 5, as no significant improvement was found except for $\mathrm{NH}_{3}$. The $\mathrm{NME}$, on the other hand, improved for $\mathrm{NH}_{3}, \mathrm{NH}_{4}^{+}$, and $\mathrm{NO}_{3}^{-}$. For the median no improvement can be seen for any species. This can be explained by the fact, that the total emissions are identical in both emission datasets and only the temporal distribution of emissions was changed. However, the prediction of peaks, represented in the 95th percentile, has improved for $\mathrm{NH}_{3}, \mathrm{NH}_{4}^{+}$and $\mathrm{NO}_{3}^{-}$. The model is now able to better reproduce the high $\mathrm{NH}_{3}$ peaks $(+14 \%)$ because the fertilizer application model allows for shorter emission peaks than the monthly STP profiles (Fig. 8). This leads to more cases in which the formation of ammonium nitrate is ammonia limited and thus reduces the modelled peaks of $\mathrm{NH}_{4}^{+}(-14 \%)$ and $\mathrm{NO}_{3}^{-}(-20 \%)$. Looking at the seasonal variability shows that these changes occur mainly during winter and spring. The changes in $\mathrm{SO}_{4}^{2-}$ concentrations are negligible, which confirms that $\mathrm{SO}_{4}^{2-}$ is not influenced by the seasonal shift of $\mathrm{NH}_{3}$ emissions. Concerning $\mathrm{PM}_{2.5}$, the NME remains almost unchanged. The negative model bias is mainly driven by an underestimation of particles during summer which is due to the underestimation of the formation of secondary organic aerosols.

\section{Discussion}

The dynamical profiles, as described and implemented in this study, result in individual hourly ammonia emissions for every grid cell considering political restrictions in the country, meteorological information, animal density, and crop types. The dynamic of the profiles becomes apparent in the emission time series for several countries presented in figure A4 (see appendix) and have been presented in earlier studies as a slight yearly shift of the peak according to the sensitivity to crop growth, which itself is sensitive to temperature (Skjøth et al., 2004). This study shows that in countries with colder winters (e.g. Germany and Denmark) spring fertilizer application peaks occur later than in countries with warmer climate such as France, the Netherlands or Ireland. The mean peak over all land grid cells appears in April, which is consistent with the results of Paulot et al. (2014) and Friedrich and Reis (2004).

In general, the DTP exhibits little similarity with the STP currently used as standard profiles for Europe AQMEII (Pouliot et al., 2012), Eurodelta III (EMEP, 2014) and COST 728 (World Meteorological Organization, 2008). The best agreement between

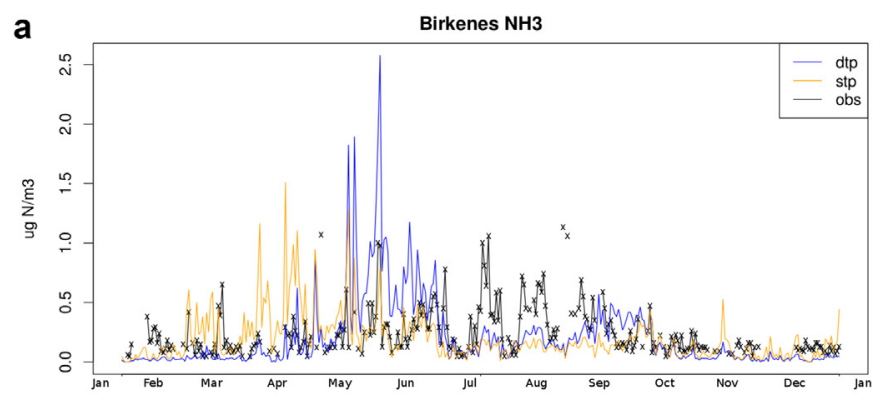

b
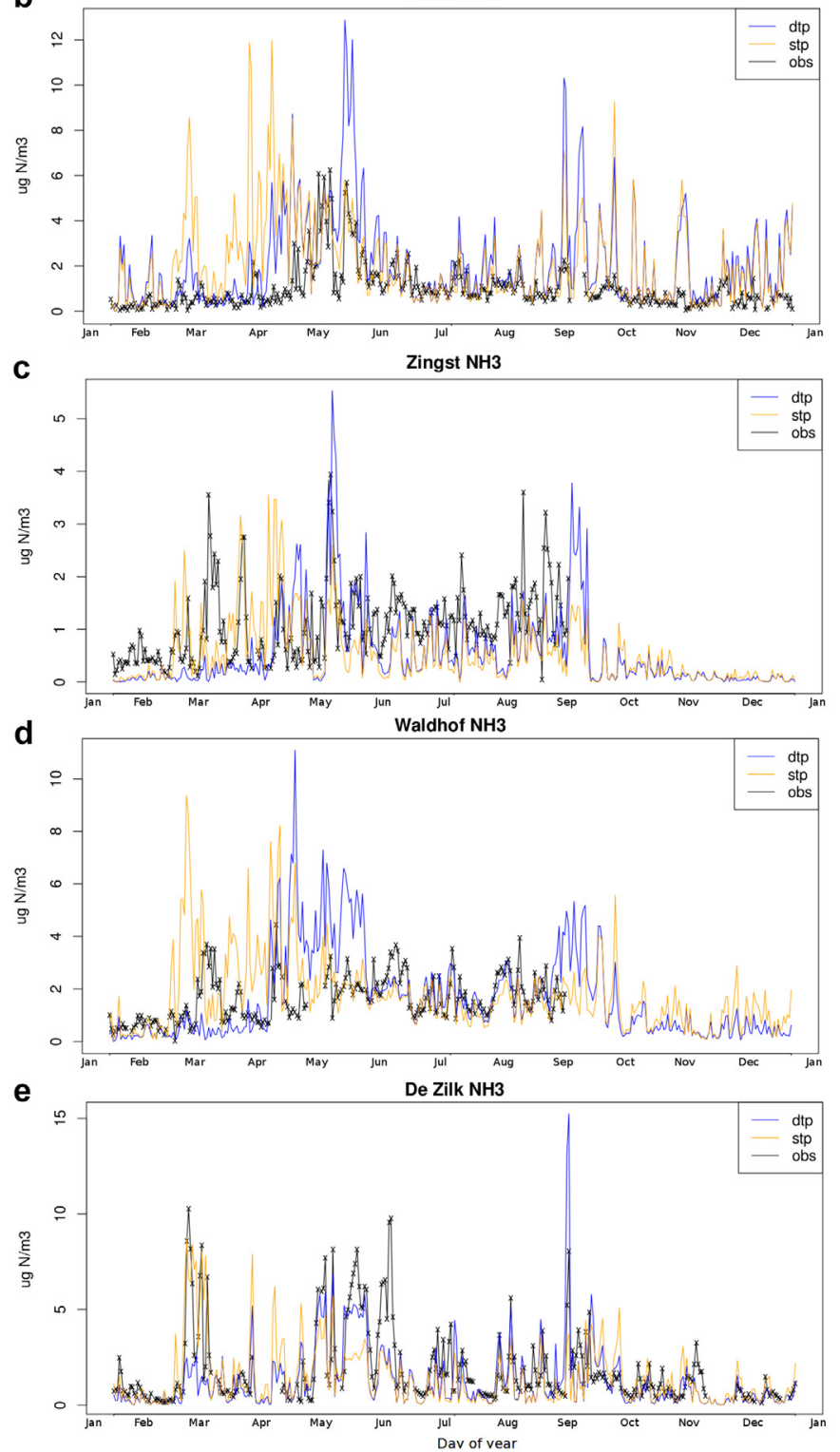

Fig. 9. Modelled (DTP: blue, STP: orange) and observed (black) ammonia concentrations for a) Birkenes, b) Tange, c) Zingst, d) Waldhof, e) De Zilk. The locations of the EMEP stations are given in the Appendix (Fig. 3 and Table A1). (For interpretation of the references to colour in this figure legend, the reader is referred to the web version of this article.)

STP and DTP, considering the time of the first spring peak, was found for Denmark. The best accordance of the STP with observed values have been found for the Netherlands (Fig. 9e), which is expected as the static profiles have been developed based on an 
Table 5

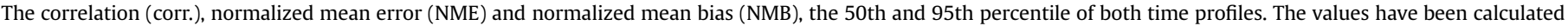
over all measured values per species presented in table A1, appendix.

\begin{tabular}{|c|c|c|c|c|c|c|c|c|}
\hline & Time profile & NME & NMB & Obs median & Model median & Obs 95 percentile & Model 95 percentile & $\mathrm{N}$ \\
\hline \multirow[t]{2}{*}{$\mathrm{NH}_{3}$} & DTP & 0.74 & -0.22 & 0.6 & 0.29 & 5.6 & 4.1 & 4599 \\
\hline & STP & 0.77 & -0.18 & 0.6 & 0.37 & 5.6 & 3.6 & 4599 \\
\hline \multirow[t]{2}{*}{$\mathrm{NH}_{4}^{+}$} & DTP & 0.59 & 0.07 & 0.48 & 0.48 & 2.48 & 2.53 & 6539 \\
\hline & STP & 0.64 & 0.18 & 0.48 & 0.52 & 2.48 & 2.95 & 6539 \\
\hline \multirow[t]{2}{*}{$\mathrm{NO}_{3}^{-}$} & DTP & 0.66 & -0.11 & 0.22 & 0.13 & 1.46 & 1.59 & 4635 \\
\hline & STP & 0.75 & 0.09 & 0.22 & 0.14 & 1.46 & 2 & 4635 \\
\hline \multirow[t]{2}{*}{$\mathrm{SO}_{4}^{2-}$} & DTP & 0.49 & 0 & 0.45 & 0.52 & 1.64 & 1.21 & 9807 \\
\hline & STP & 0.5 & -0.02 & 0.45 & 0.53 & 1.64 & 1.26 & 9807 \\
\hline \multirow[t]{2}{*}{$\mathrm{PM}_{2.5}$} & DTP & 0.55 & -0.45 & 8.33 & 3.68 & 23.58 & 16.05 & 2147 \\
\hline & STP & 0.54 & -0.39 & 8.33 & 3.78 & 23.58 & 19.11 & 2147 \\
\hline
\end{tabular}

experimental data set of this area (Schaap et al., 2004). These results are in line with those of a previous study of van Damme et al. (2014).

In summary, the implementation of the DTP resulted in a shift from seasonal average winter $\mathrm{NH}_{3}$ emissions to summer emissions, as also found by Pinder et al. (2006) in a study comparing an inventory with constant emissions with a process-based and inversemodelled one. Furthermore, the spring peak occurs later in the year for most climates and an additional autumn emission peak due to manure application is visible. An evaluation of the results at the seasonal level showed that the improvements of the correlation coefficient are mainly attributable to an improvement in spring, when the correlation has improved significantly for most stations, while the smallest changes were observed during summer. Nevertheless the DTP tends to overestimate the manure application and therefore the ammonia emissions in the peaks (Fig. 9). At the same time the winter emissions seem to be underestimated. This could be also due to an underestimation of the Manure Management sector in the EDGAR dataset.

As presumed by Sutton et al. (2012) the use of different time profiles for the emission data account for different atmospheric concentrations. Although the annual total emissions were unchanged, the implementation of the DTP resulted in a $12 \%$ decrease of $\mathrm{PM}_{2.5}$ concentrations over the whole model domain. This affects mostly concentrations during winter $(-20 \%)$, while summer concentrations are similar in both model runs $(+3 \%)$. This can be explained by the reduced availability of ammonia during winter, which resulted in a reduction of ammonium nitrate formation in this season. These strong effects of reduced $\mathrm{NH}_{3}$ emissions during winter on the particle formation are confirmed by other studies (Megaritis et al., 2013; Aksoyoglu et al., 2011). In contrary to what was found by Megaritis et al. (2013), in this study the atmospheric concentration of ammonium sulphate was not affected by the implementation of the DTP. This indicates that, in our study, the formation of sulphate particles is only limited by $\mathrm{SO}_{2}$ and the related availability of sulphuric acid. The additional $\mathrm{NH}_{3}$ emission peak in autumn did not lead to increased formation of secondary aerosols. In fact, the seasonal average $\mathrm{PM}_{2.5}$ concentration is even slightly lower than in the STP model run. This indicates that the ammonium nitrate formation during autumn is limited by $\mathrm{NO}_{\mathrm{x}}$ emissions controlling the availability of nitric acid. Moreover, it can be deduced that short peaks with high ammonia emissions have a smaller impact on particle formation than steady emissions over a longer period, because the ammonium nitrate formation will be limited by the availability of nitric acid during the peak events. Moreover, the missing reflection of the September emission peak in the concentration of $\mathrm{NH}_{4}^{+}$and $\mathrm{NO}_{3}^{-}$can be explained as follows: $\mathrm{NO}_{\mathrm{x}}$ emissions are still relatively low because the heating season has not started yet. In addition, condensation processes are less effective at high temperatures and low humidity. Finally, the reduction of ammonium nitrate formation using the DTP leads to an increase in gaseous nitric acid concentrations during winter and spring. This is in line with observations (Fig. A5).

\section{Conclusions}

In this study, the influence of improved temporal profiles for $\mathrm{NH}_{3}$ emissions on atmospheric ammonia concentrations and the formation of the secondary aerosols $\mathrm{NH}_{4}^{-}, \mathrm{NO}_{3}^{-}$and $\mathrm{SO}_{4}^{2-}$ has been investigated. As expected, the influence varies with season, due to different meteorological conditions in winter and summer. The formation of particles is favoured by humid and cold winter conditions, which is why the decrease of $\mathrm{NH}_{3}$ emissions in this season, as seen in the DTP (Fig. 2), leads to a strong effect on the formation of $\mathrm{NO}_{3}^{-}, \mathrm{NH}_{4}^{+}$and $\mathrm{PM}_{2.5}$ (Table 5). As a result of the decrease in particulate $\mathrm{NO}_{3}^{-}$the concentration of gaseous $\mathrm{HNO}_{3}$ is increasing (Fig. A5). An influence on the formation of $\mathrm{SO}_{4}^{2-}$ could not be seen, due to the favourable role of sulphuric acid as a reaction partner of $\mathrm{NH}_{3}$. On annual average the reduced formation of ammonium nitrate in the DTP scenario leads to a reduction of the $\mathrm{PM}_{2.5}$ concentration by $12 \%$.

It can be concluded that due to the shift of $\mathrm{NH}_{3}$ emissions from the colder seasons into the warmer seasons the correlation between modelled and observed $\mathrm{NH}_{3}$ concentrations has improved significantly for 12 out of 16 EMEP measurement stations used for the model evaluation. At the same time the influence on the particle formation in general is driven by too many factors to directly affect the correlation with other gaseous or particulate substances involved. Nevertheless, the influence on the mean concentrations of secondary aerosols can be seen in the improvement of the NME for $\mathrm{NH}_{4}^{+}$and $\mathrm{NO}_{3}^{-}$. At the same time, the NME and NMB of particulate $\mathrm{SO}_{4}^{2-}$ has not changed at all, so that it can be concluded that there is still enough $\mathrm{NH}_{3}$ in the atmosphere to saturate the formation process of $\mathrm{SO}_{4}^{2-}$ particles in every season.

The improved agreement in correlation between modelled and measured atmospheric concentrations of $\mathrm{NH}_{3}$, and in particular the reduced error for many relevant particulate species underlines both the plausibility of the here presented approach and the importance of considering seasonal variations for ammonia emissions. Furthermore, the multi-sectoral structure of the disaggregation methods qualifies this model for performing sophisticated scenario evaluations. The evaluation and the comparison of the results with findings of current scientific investigations suggest that the use of a dynamical profile is necessary for studies assessing the impact of ammonia abatement strategies. However, the underlying data, based on the EDGAR emission dataset, could be improved in former studies concerning their geographically distribution as well as their sectoral distinction between ammonia emissions from fertilizer application, manure management, and animal husbandry. 


\section{Appendix A. Supplementary data}

Supplementary data related to this article can be found at http:// dx.doi.org/10.1016/j.atmosenv.2016.01.041.

\section{References}

Aksoyoglu, S., Keller, J., Barmpadimos, I., Oderbolz, D., Lanz, V.A., Prévôt, A.S.H., Baltensperger, U., 2011. Aerosol modelling in Europe with a focus on Switzerland during summer and winter episodes. Atmos. Chem. Phys. 11 (14), 7355-7373. http://dx.doi.org/10.5194/acp-11-7355-2011.

Anderson, N., Strader, R., Davidson, C., 2003. Airborne reduced nitrogen: ammonia emissions from agriculture and other sources. Environ. Int. 29 (2-3), 277-286. http://dx.doi.org/10.1016/S0160-4120(02)00186-1.

Aneja, V.P., Schlesinger, W.H., Erisman, J.W., 2009. Effects of agriculture upon the air quality and climate. Res. Policy, Regul. 43, 4234-4240.

Backes, A.M., Aulinger, A. Bieser, J. Matthias, V., Quante, M., 2015. Ammonia Emissions in Europe, Part II: How Ammonia Emission Abatement Strategies Affect Secondary Aerosols. AE accepted.

Bieser, J., Aulinger, A., Matthias, V., Quante, M., Builtjes, P., 2011. SMOKE for Europe - adaptation, modification and evaluation of a comprehensive emission mode for Europe. Geosci. Model Dev. 4 (1), 47-68. http://dx.doi.org/10.5194/gmd-447-2011.

Binkowski, F.S., Roselle, S.J., 2003. Models-3 community multiscale air quality (CMAQ) model aerosol component, 1. model description. J. Geophys. Res. 108, 4183. http://dx.doi.org/10.1029/2001JD001409.

Byun, D.W., Ching, J.K.S., 1999. Science Algorithms of the EPA Models-3 Community Multi-scale Air Quality (CMAQ) Modeling System, EPA/600/R-99/030. US EPA National Exposure Research Laboratory, Research Triangle Park, NC.

Byun, D.W., Schere, K.L., 2006. Review of the governing equations, computational algorithms, and other components of the models- 3 community multiscale air quality (CMAQ) modeling system. Appl. Mech. Rev. 59 (2), 51-77.

van Damme, M., Kruit, R.J.W., Schaap, M., Clarisse, L., Clerbaux, C., Coheur, P., 2014 Evaluating 4 years of atmospheric ammonia (NH 3) over Europe using IASI satellite observations and LOTOS-EUROS model results. J. Geophys. Res. 9549-9566. http://dx.doi.org/10.1002/2014JD021911.

De Vries, W., Leip, A., Reinds, G.J., Kros, J., Lesschen, J.P., Bouwman, A.F., 2011 Comparison of land nitrogen budgets for European agriculture by various modeling approaches. Environ. Pollut. (Barking, Essex 1987) 159 (11) 3254-3268. http://dx.doi.org/10.1016/j.envpol.2011.03.038.

TNO Report Denier van der Gon, H.D., Hendriks, C., Kuenen, J., Segers, A. Visschedijk, A., 2011. Description of Current Temporal Emission Patterns and Sensitivity of Predicted AQ for Temporal Emission Patterns. EU FP7 MACC deliverable report D_D-EMIS_1.3.

Dentener, F., Drevet, J., Lamarque, J.F., Bey, I., Eickhout, B., Fiore, A.M., Hauglustaine, D., Horowitz, L.W., Krol, M., Kulshrestha, U.C., Lawrence, M., GalyLacaux, C., Rast, S., Shindell, D., Stevenson, D., Van Noije, T., Atherton, C., Bell, N., Bergman, D., Butler, T., Cofala, J., Collins, B., Doherty, R., Ellingsen, K., Galloway, J., Gauss, M., Montanaro, V., Müller, J.F., Pitari, G., Rodriguez, J. Sanderson, M., Solmon, F., Strahan, S., Schultz, M., Sudo, K., Szopa, S., Wild, O., 2006. Nitrogen and sulfur deposition on regional and global scales: a multimodel evaluation. Glob. Biogeochem. Cycles 20 (4). http://dx.doi.org/10.1029/ 2005GB002672 n/a-n/a.

Doms, G., Schättler, U., 2002. A Description of the Nonhydrostatic Regional Mode LM. Part I: Dynamics and Numerics. Tech. rep.. Deutscher Wetterdienst www. cosmomodel.org/content/model/documentation/core/default.htm (18.11.14.).

EC, 1991. Council Directive 91/676/EEC of 12 December 1991 concerning the protection of waters against pollution caused by nitrates from agricultural sources. Off. J. Eur. Commun. 375, 1-8.

EC, 2009. Study on Variation of Manure N Efficiency throughout Europe. Annex1. http://ec.europa.eu/environment/water/water-nitrates/pdf/Annex_1_Man_N Effic.pdf.

EDGAR, 2009. Emission Database for Global Atmospheric Research (EDGAR) version 4.0. EC-JRC/PBL. http://edgar.jrc.ec.europa.eu (11.11.14.).

EMEP, 2014. The EURODELTA III exercise. In: Model Evaluation with Observations Issued from the 2009 EMEP Intensive Period and Standard Measurements in Feb/Mar 2009 (08.01.2015).

Erisman, J.W., Sutton, M.A., Galloway, J., Klimont, Z., Winiwarter, W., 2008. How a century of ammonia synthesis changed the world. Nat. Geosci. 1, 636-639.

European Environmental Agency, 2007. EMEP/CORINAIR Emission Inventory Guidebook. EEA, 1049 Brussel, Belgium. Technical Report No. 16/2007.

Eurostat, 2014. Land Use - 1000 ha - Annual Data, Utilized Agricultural Area. Last update: 29-01-2014. http://appsso.eurostat.ec.europa.eu/nui/show.do? dataset=apro_cpp_luse\&lang=en (18.11.14.)

FAO, 2007. Gridded Livestock of the World 2007. G.R.W.Wint and T.P.Robinson. http://www.fao.org/Ag/againfo/resources/en/glw/home.html (11.11.14.)

FAOSTAT, 2014. Agriculture Environmental Indicators, Air and Climate Change. http://data.fao.org/dataset-data-filter?entryld=f25df775-e5da-4170-bc16ef4ec030144f\&tab=data (accessed 12.04.14.).

Fowler, D., Coyle, M., Skiba, U., Sutton, M.A., Cape, J.N., Reis, S., Sheppard, L.J. Jenkins, A., Grizzetti, B., Galloway, J.N., 2013. The global nitrogen cycle in the twenty-first century. Trans. R. Soc. B Biol. Sci. 368, 20130164.

Friedrich, R., Reis, S., 2004. Emissions of Air Pollutants: Measurements, Calculations and Uncertainties. Springer, Berlin Heidelberg, New York.

van Grinsven, H.J.M., Holland, M., Jacobsen, B.H., Klimont, Z., Sutton, M. Willems, W.J., 2013. Costs and benefits of nitrogen for europe and implications for mitigation. Environ. Sci. Technol. 47, 3571-3579.

Gyldenkærne, S., Skjøth, C.A., Hertel, O., Ellermann, T., 2005. A dynamical ammonia emission parameterization for use in air pollution models. J. Geophys. Res. http://dx.doi.org/10.1029/2004JD005459.

Hertel, O., et al., 2011. Nitrogen processes in the atmosphere. In: Sutton, M.A., Howard, C.M., Erisman, J.W., Billen, G., Bleeker, A., Grennfelt, P., Grinsven van, H., Grizzetti, B. (Eds.), The European Nitrogen Assessment. Published by Cambridge University Press, pp. 177-208.

Hristov, A.N., 2011. Technical note: contribution of ammonia emitted from livestock to atmospheric fine particulate matter (PM2.5) in the United States. J. Dairy Sci. 94 (6), 3130-3136.

Huang, X., Song, Y., Li, M., Li, J., Huo, Q., Cai, X., Zhu, T., Hu, M., Zhang, H., 2012. A high-resolution ammonia emission inventory in China. Glob. Biogeochem. Cycles 26 (1). http://dx.doi.org/10.1029/2011GB004161 n/a-n/a.

Huijnen, V., Williams, J.E., van Weele, M., van Noije, T.P.C., Krol, M.C., Dentener, F., Segers, A., Houweling, S., Peters, W., de Laat, A.T.J., Boersma, K.F. Bergamaschi, P., van Velthoven, P.F.J., Le Sager, P., Eskes, H.J., Alkemade, F., Scheele, M.P., Nédélec, P., Pätz, H.-W., 2010. The global chemistry transport model TM5: description and evaluation of the tropospheric chemistry version 3.0. Geosci. Model Dev. Discuss. 3, 1009-1087. http://dx.doi.org/10.5194/gmdd3-1009-201010.5194/gmdd-3-1009-2010. http://www.geosci-model-devdiscuss.net/3/1009/2010/.

Hutchings, N.J., Sommer, S.G., Andersen, J.M., Asman, W.A.H., 2001. A detailed ammonia emission inventory for Denmark. Atmos. Environ. 35, 1959-1968.

Megaritis, A.G., Fountoukis, C., Charalampidis, P.E., Pilinis, C., Pandis, S.N., 2013. Response of fine particulate matter concentrations to changes of emissions and temperature in Europe. Atmos. Chem. Phys. 13 (6), 3423-3443. http:// dx.doi.org/10.5194/acp-13-3423-2013.

Mikkelsen, M.H., Albrektsen, R., Gyldenkærne, S., 2011. Danish Emission Inventories for Agri- Culture. Inventories 1985-2009. National Environmental Research Institute, Aarhus University, p. 136. NERI Technical Report No. 810. http://www. dmu.dk/Pub/FR810.pdf.

Nenes, A., Pandis, S.N., Pilinis, C., 1998. ISORROPIA: a new thermodynamic equilibrium model for multiphase multicomponent inorganic aerosols. Aquat. Geochem. 4, 123-152.

Paulot, F., Jacob, D.J., Travis, K., 2014. Ammonia emissions in the United States, European Union, and China derived by high-resolution inversion of ammonium wet deposition data: interpretation with a new agricultural emissions inventory (MASAGE_NH3). J. Geophys. Res. 4343-4364. http://dx.doi.org/ 10.1002/2013JD021130.

Pinder, R.W., Adams, P.J., Pandis, S.N., 2007. Ammonia emission controls as a costeffective strategy for reducing atmospheric particulate matter in the Eastern United States, 41 (2), 380-386.

Pinder, R.W., Adams, P.J., Pandis, S.N., Gilliland, A.B., 2006. Temporally resolved ammonia emission inventories: current estimates, evaluation tools, and measurement needs. J. Geophys. Res. 111 (D16), D16310. http://dx.doi.org/10.1029/ 2005JD006603.

Pouliot, G., Pierce, T., Denier van der Gon, H., Schaap, M., Moran, M., Nopmongcol, U., 2012. Comparing emission inventories and model-ready emission datasets between Europe and North America for the AQMEII project. Atmos. Environ. 53 (January), 4-14. http://dx.doi.org/10.1016/ j.atmosenv.2011.12.041.

Reis, S., Skjøth, A.C., Vieno, M., Geels, C., Steinle, S., Lang, M., Sutton, M.A., 2011. Why time and space matters-arguments for the improvement of temporal emission profiles for atmospheric dispersion modeling of air pollutant emissions. In: MODSIM 2011-19th International Congress on Modelling and SimulationSustaining Our Future: Understanding and Living with Uncertainty, pp. $1817-1823$.

Rockel, B., Geyer, B., 2008. The performance of the regional climate model CLM in different climate regions, based on the example of precipitation. Meteorol. Z. 17 (4), 487-498.

Rockel, B., Will, A., Hense, A., 2008. The regional climate model COSMO-CLM (CCLM). Meteorol. Z. 17 (4), 347-348.

Schaap, M., van Loon, M., ten Brink, H.M., Dentener, F.J., Builtjes, P.J.H., 2004. Secondary inorganic aerosol simulations for Europe with special attention to nitrate. Atmos. Chem. Phys. 4 (3), 857-874. http://dx.doi.org/10.5194/acp-4-8572004.

Schaap, M., Roemer, M., Sauter, F., Boersen, G., Timmermans, R., 2005. LOTOSEUROS : Documentation. http://www.lotos-euros.nl/doc/LOTOS-EUROS-v11documentation.pdf (17.11.14.).

Schulze, E.D., Ciais, P., Luyssaert, S., Schrumpf, M., Janssens, I.A., Thiruchittampalam, B., Theloke, J., Saurat, M., Bringezu, S., Lelieveld, J., Lohila, A., Rebmann, C., Jung, M., Bastviken, D., Abril, G., Grassi, G., Leip, A., Freibauer, A., Kutsch, W., Don, A., Nieschulze, J., Börner, A., Gash, J.H., Dolman, A.J., 2010. The European carbon balance. Part 4: integration of carbon and other trace-gas fluxes. Glob. Change Biol. 16 (5), 1451-1469. http:// dx.doi.org/10.1111/j.1365-2486.2010.02215.x.

Seinfeld, H.J., Pandis, N.S., 1998. Atmospheric Chemistry and Physics. Wiley, New York (Seinfeld and Pandis, 1998).

Skjøth, C.A., Geels, C., Berge, H., Gyldenkærne, S., Fagerli, H., Ellermann, T. Frohn, L.M., Christensen, J., Hansen, K.M., Hansen, K., Hertel, O., 2011. Spatial and temporal variations in ammonia emissions - a freely accessible model code 
for Europe. Atmos. Chem. Phys. 11 (11), 5221-5236. http://dx.doi.org/10.5194/ acp-11-5221-2011.

Skjøth, C.A., Hertel, O., Gyldenkærne, S., Ellermann, T., 2004. Implementing a dynamical ammonia emission parameterization in the large-scale air pollution model ACDEP. J. Geophys. Res. 109 (D6), D06306. http://dx.doi.org/10.1029/ 2003JD003895.

Sutton, M.A., van Grinsven, H., et al., 2011. Summary for policy makers. In: Sutton, M.A., Howard, C.M., Erisman, J.W., Billen, G., Bleeker, A., Grennfelt, P., Grinsven van, H., Grizzetti, B. (Eds.), The European Nitrogen Assessment. Published by Cambridge University Press, pp. xxiv-xxxiv.

Sutton, P., Chemel, C., Griffiths, S., Sokhi, R.S., 2012. Investigation, using CMAQ of sensitivity of air quality modelling to input ammonia emissions. In: Air Pollution Modelling and its Application XXII. Proceedings of the 32nd NATO/SPS International Technical Meeting on Air Pollution Modelling and its Application. Utrecht, the Netherlands, September 7 e 11 May 2012.

Velthof, G.L., Bruggen, van, C., Groenestein, C.M., de Haan, B.J., Hoogeveen, M.W. Huijsmans, J.F.M., 2012. A model for inventory of ammonia emissions from agriculture in the Netherlands. Atmos. Environ. 46, 248-255. http://dx.doi.org/ 10.1016/j.atmosenv.2011.09.075

Velthof, G.L., Lesschen, J.P., Webb, J., Pietrzak, S., Miatkowski, Z., Pinto, M., et al.Oenema, O., 2014. The impact of the nitrates Directive on nitrogen emissions from agriculture in the EU-27 during 2000-2008. Sci. Total Environ. 468-469 (3), 1225-1233. http://dx.doi.org/10.1016/j.scitotenv.2013.04.058.

Webb, J., Sørensen, P., Velthof, G., Amon, B., Pinto, M., Rodhe, L., Salomon, E. Hutchings, N., Burczyk, P., Reid, J., 2010. Final Report Study on Variation of Manure N Efficiency throughout Europe, 1-114. http://ec.europa.eu/ environment/water/water-nitrates/pdf/Man_N_Eff_FinalReport.pdf (12.05.2014)

Werner, M., Kryza, M., Dore, A.J., 2014. Differences in the spatial distribution and chemical composition of PM10 between the UK and Poland. Environ. Model. Assess. 19, 179-192. http://dx.doi.org/10.1007/s10666-013-9384-0.

World Meteorological Organization, 2008. GAW Report No. 177, Joint Report of COST Action 728 and GURME Overview of Existing Integrated (off-line and on-line) Mesoscale Meteorological and Chemical Transport Modelling Systems in Europe (08.1.2015). 